\title{
The Impact of a Pandemic to be Strengthening Artist Tolerance in Facing C-19 Through Digital Art
}

\author{
Ariesa Pandanwangi*, Belinda Sukapura Dewi \\ Department of Fine Art \\ Universitas Kristen Maranatha \\ Bandung, Indonesia \\ *ariesa.pandanwangi@maranatha.edu, \\ belinda.s.dewi@gmail.com
}

\author{
Nuning Yanti Damayanti \\ Department of Fine Art \\ Institut Teknologi Bandung \\ Bandung, Indonesia \\ nuning@fsrd.itb.ac.id
}

\author{
Arleti Mochtar Apin \\ Department of Textile \\ Institut Teknologi Harapan Bangsa \\ Bandung, Indonesia \\ arleti@ithb.ac.id
}

\begin{abstract}
Covid Pandemic-19 as a world disaster, which claimed the lives of people. Among these tragic things, world artists increased their adrenaline creativity, they delivered subject matter about how to protect themselves, invitations to wear masks, how to wash their hands, and many other topics when working from home. One of the platforms created during the pandemic is ASEDAS (ASEAN digital art community). This platform can reach 32 participating countries with 500 digital works. The problem in this research is how the visualization of artwork created by artists. The purpose of writing this article is to determine the tolerance of artists in the pandemic period created through digital artwork. Analysis of the work from the Asian region highlights many unique local potentials in the country, while those from abroad, especially Europe, prioritize communicative subject matter, center of composition, attractive colors, and open images that are easy to read by invited viewers. to always protect and maintain health. These results will be involved in enhancing craft creativity in a period that can be used for further research.
\end{abstract}

Keywords-Covid 19, digital art, pandemic

\section{INTRODUCTION}

The world facing a serious problem due to this virus Covid19 [1], no one ever think that effect of such a tiny little creature can make whole world in chaotic, economy stop completely, all activities are also cease [2]. Arousing fear, panic even paranoid among each human being, and this is not helping anything at all [3]. No one knows the real situation and assuming with their own perception not a relieve either. Artists are also affected, exhibitions are pending or even cancelled, galleries and art center being close no performance nor show are held [3].
Conditions like this make many people frustrated, because activities are hampered, even some are related to financial problems as well [4]. Of course, a solution must be found to work on this situation and can help many people out of this problem. Base on this, idea to create an activity was born, started then started through discussions with several acquaintances. From Indonesia and Malaysia this activity started, agreed to create a community and carry out joint activities. ASEDAS (ASEAN digital art community) born to accommodate a virtual exhibition. Participants are not only from Asia but extend to many countries.

Working from home became a must in this situation. Painting, drawing, making art are real activities, directly intersecting with actual tools, materials and the environment [5]. Every movement, the strokes of the color of the media touch, are a sensation that is felt by each artist. Especially for the artists who prefer to work manually because the gesture will give their own expression. Culminate satisfaction is the sense experienced by the artist when creating a work of art. To be able to touch, feel and rub materials are giving chance to explore in processing artwork. Quite a number of artists developing more of their ideas along the process of making the work, new possibilities are found as they explored.

For artist who do not familiar working with computer will find difficulties in creating artwork. They need to know stages of every single steps in order to create some simple thing done by their hands. Working speed can be slowed down to one are not habitual in computer system. Can be frustrated in making a very simple step which will be done in a split second manually. It is uneasy to be creative with new media. Other problem faced is about finding the appropriate software to use for each task. 


\section{MethodS}

\section{A. Method Used}

This research employs the qualitative method. The data are taken by using the related literature [6]. The descriptive method is used to analyze data by interpreting visual narration of the artwork creation of joint exhibition under the ASEAN Digital Art Society (ASEDAS) in the 1st International Virtual Digital Art Exhibition, 'ASEDAS 2020: With the theme "Solidarity against COVID-19". It is hoped that digital art exhibition activities will inspire and arouse public awareness to be optimistic and creative together to face the difficult conditions and changes in the order of life that have occurred due to the Covid19 pandemic.

\section{B. Steps of the Study}

To find out which works of art have visualizations according to the pandemic theme, an initial study was carried out by searching for data through websites that display online exhibitions. The results of the data show that the largest online exhibition event during the covid-19 period was an international exhibition broadcast online by ASEDAS (ASEAN Digital Art Society) and organized by two countries, namely Indonesia and Malaysia. This exhibition received responses participants from 34 Asian, European, American and African countries, a total of 354 participants who have made more than 500 works of art with the theme of solidarity against covid-19 [7]. This exhibition was conducted by utilizing digital technology and virtual communication media through internet technology networks to establish connections and the link between the art world and its viewers. Participants who took part in this exhibition were divided into 3 categories, namely 1) Professionals such as academics, 2) artists, 3) students. After the data was recorded and sorted, works that brought local content from each country were selected. The works is also the choice of international curators. The selected works were identified and analyzed using Feldman's theory.

\section{RESUlt AND DiscUSSION}

In this study some of the works of participants from Asian will be reviewed. Participants in the exhibition were dominated by participants from Indonesia, Malaysia, then African, Iran, China, Thailand, Singapore, Japan, India, South Korea, Palestine and Syria and then from Africa, namely Egypt. In particular, the works of participants from Asian countries have a distinctive feature, namely works with illustrative genres among various other genres that have emerged, namely realist, abstract, pop art, photography posters with contemporary styles.

Interesting enough illustrative work that immediately catches attention is the power of narrative which can be specific in the sociology of Asian and African societies. The illustration work in this exhibition has a unique composition of visual elements so that in addition to being aesthetically pleasing, it can also communicate messages according to its purpose without having to have a slogan or explanatory typography. What is strong in a work in the form of a poster is the richness of the dominant visual elements as objects in the work, the form of corona / covid-19 always appears, in addition to idioms and objects that support its delivery. message visually. There is no need to question this as the theme of this exhibition is solidarity with the Vicod-19.

\section{A. Shifting Manual Work to Digital}

Working with computers is to prepare basic knowledge of the working logic of the media. In this case, explore how the software works on a computer. Like any media we need to know the way it works best, so is with computers or digital media. One can start from the beginning of an empty field or start from processing, but this requires some skill. Another possibility working with images from your own existing photos. By using an image to start with save time so will speed up the work process. Cropping, rearrange, twisting and many other probabilities of creating a new piece of an image. Working with computer can be fun and full of surprise which take longer done manually. Changing range of colors need only seconds, compare to hours hand work, certainly. Features provide in the software should be explored until the edge to comply our need.

\section{B. Creativity has no Limitation}

Human ability which became the advantage and computers could never have is creativity. Human mind has unlimited ideas, thinking power, analytic thinking, and promptness. Visual stimuli obtained from digital processing can stimulate the way artists develop ideas [8]. Tools only help speed up the work of its users [9]. Batik is a piece of resist dye drawing technique, require specific skill and medium. Like any medium, batik also have excellence as well as weakness. The use of computer can do things that impossible done by batik technique. Enhancing visual image using possibility provide in the software allow another prospect. An image provides unlimited new images, totally different from the original piece. The higher skill the countless output. The more explorations the richer image results.

\section{Virtual art live}

Pandemic situation due to Covid-19 slow down many activities, including artists work. Being to work from home away from material supplies enable to produce real piece of artwork [10]. But with effort and creativity, it shall not be a serious obstacle. Digital era give chance to do more in this situation. Adaptation needed to adjust us but should be proceed soon [11]. A piece of Batik cloth for instance turn into a new digital artwork.

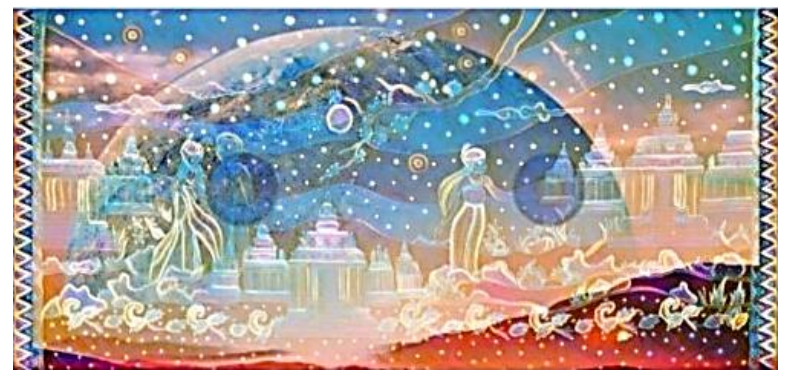

Source: shorturl.at/coz18

Fig. 1. Roro Jonggrang vs Covid 19. 
The visualization of this work (figure 1) was inspired by the batik cloth telling the story of Roro Jonggrang [12,13]. The artist processed it into a pandemic theme made with digital art, so it seems that this work carries the message that even legendary figures in folklore use mask, especially those of us who live in the millennial era. Roro Jonggrang is a well-known legend from Central Java [14]. The revival of this story is linked to the current situation, the spread of the COVID 19. This work is used visuals layers. Layers appear transparent and light. As if floating and surrounded by the COVID virus that dominates space. Roro is known for circulating the story behind the creation of the Prambanan temple. One of the statues in the temple is believed to be the embodiment of Roro Jonggrang who was cursed to stone by Prince Bandung Bondowoso. This curse originated from Bandung Bondowoso's anger at Roro Jonggrang's cheating which caused him to be unable to complete the construction of 1,000 temples [15].

In this work, the two figures are depicted close together. Roro Jonggrang is shown running to the right and Bandung Bondowoso, who has the strength, precedes Roro Jonggrang to accept his love. Then visually, Roro Jonggrang looks clearer than Bandung Bondowoso, which is opaquer and more covered in circles like wheels as a sign of his strength.

The depiction of the story and the main characters in the work are in a separate circle from the supporting images. The figures of Roro Jonggrang and Bandung Bondowoso are drawn bigger than the palace, even though the object of the palace is actually in front of them. In addition, the use of the visual language of NPM (Naturalist Perspective Moment Opname) on palace objects is very clear because of the perspective [16]. The rooms and palace details are displayed in detail to show the reality of the palace. This is different from the depiction of RWD (Flat Time Space) found in the main character of this story. The two technical joints in this work are very good and look natural. The composition of blue and orange is mutually reinforcing and looks harmonious. The complementary color of blue orange emphasizes the existence of different spaces, such as the space in the foreground, the main character's room, the supporting room, and the sky.

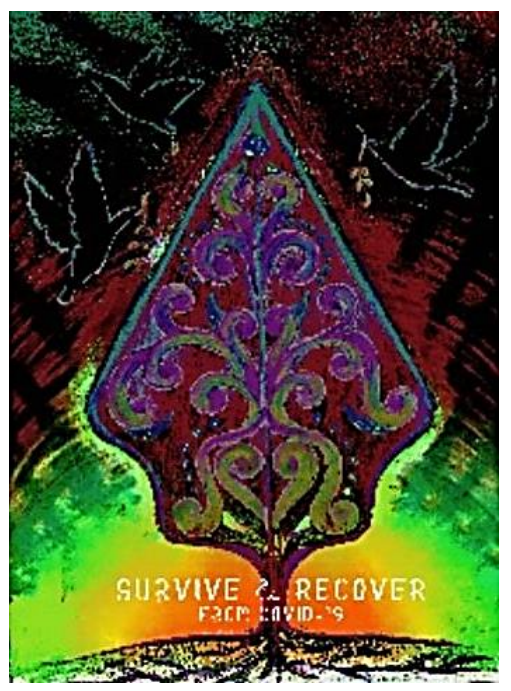

Source: shorturl.at/alpB3

Fig. 2. Survive \& Recover
In Javanese culture, 'Gunungan' is a symbol of the universe. In Survive \& Recover (figure 2), gunungan is depicted right in the middle [17]. Its balanced composition illustrates the power of the universe that can heal and help humans from the COVID 19 virus attack. The stable impression of the composition of the gunungan is reflected in the mountains themselves. Although the patterns are made using expressive brush strokes, this does not create an expressive impression because between the left and right sides are placed decorations. If the gunungan is divided into two, the two types of decorations have something in common, so that it looks stable.

The use of analogue colors in the background and the presence of a gunungan pattern gives a harmonious impression. In addition, even though there is the addition of green, the color composition of the gunungan does not become noisy, because the color only emphasizes or emphasizes some parts of the pattern. The composition of yellow to orange at the bottom and bright green intersecting with dark red on both sides of the lower gunungan gives a strong impression, both from the light emitted by orange and green colors. This impression seems to indicate the power for healing or resistance. This can be seen from the placement of the two contrasting colors, namely the dark color at the top and the light color at the bottom.

The depiction of the stalks of the gunungan that turn into roots that spread down the left and right of the work, as if taking power from the earth to fight the COVID 19 virus. This composition energizes the work.

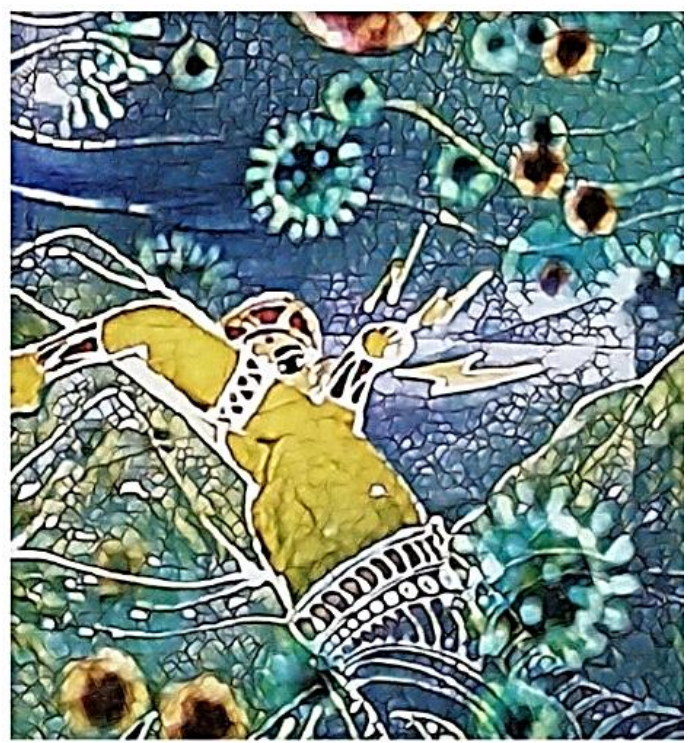

Source: shorturl.at/blpGX

Fig. 3. Eradicate Covid 19

The work with the title Eradicate Covid-19 (figure 3) is show a woman from the side (distinctive looking) hand holding up, as if fending off the virus that is coming repeatedly [18]. In addition, appear yellow flashes approaching the face and shoulders, making the figures in this work look as if they are being terrorized and cornered, surrounded by the virus that surrounds them. The composition of this work is diagonal towards the bottom corner. The face in the figure is shown facing the observer with an alert expression and a sharp gaze 
(front view). Visual language depiction is used on figure objects. This can be seen from the body of the figure drawn from the side view with the face drawn from the front view. In addition, the Covid-19 virus is drawn larger than the original because it is considered important and the lines at the back represent the motion of the virus.

This work uses yellow, green, blue, and dark blue (analogues) colors, which are arranged gradually from the lower left corner with a yellow arrangement, blue and white from light, and green in the upper right. The brown color is spread on the lower left of the crown arm, the back, and the upper right as a counterweight. The main character's clothes are the focus (point of interest), while the green color of COVID is placed in the center and bottom left and spreads upwards to balance and unify the composition.

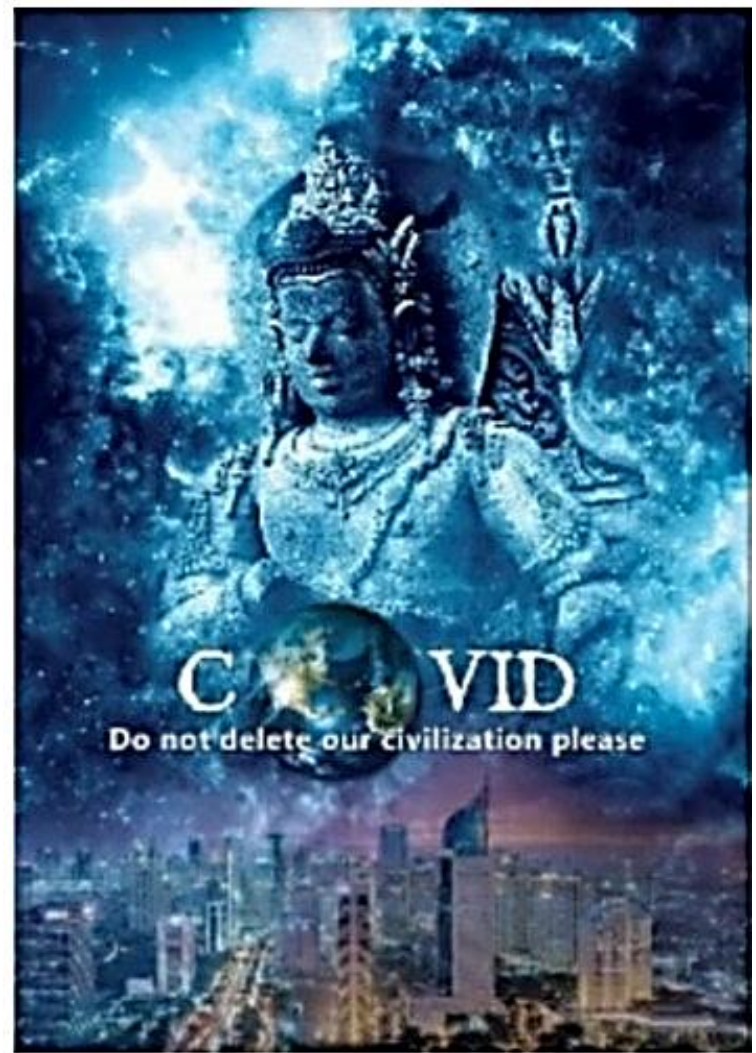

Source: shorturlat/asGY8

Fig. 4. Save civilization

This poster design (figure 4): Save Civilization is depicted Vishnu Deva who is the preserving deity [19]. This statue is drawn at the top with a view of the metropolitan city at the bottom. The city on this poster has a nighttime background, visible from the lights on the street and several parts of the building. On the center of the poster put a globe that replaces the letter $\mathrm{O}$ in the writing of COVID and right below it is the words Do not delete our civilization please in a smaller font size.

The overall poster image places Vishnu Deva and the writing of COVID in an important position because it is in the middle and its size dominates the composition of the poster. The placement of the globe in the center gives the impression that the world is under the protection of Vishnu. Monochrome colors from blue to white dominate $3 / 4$ part of the poster and are the place where Vishnu resides, so that the colors and objects in this section have a dominant position. The appearance of a graded blue and white color makes the impression of 3 dimensions and space feel more alive and the placement of dark blue on the left of the letter e, the right side of the face, and the top right balances the light blue color on the right of the letter d, arms, clothes, and parts left face upwards.

The rest of the $1 / 4$ section uses different colors, purple, light purple, and yellow on the border and yellow on the bottom right. The use of this color gives a warmer impression than the $3 / 4$ above it.

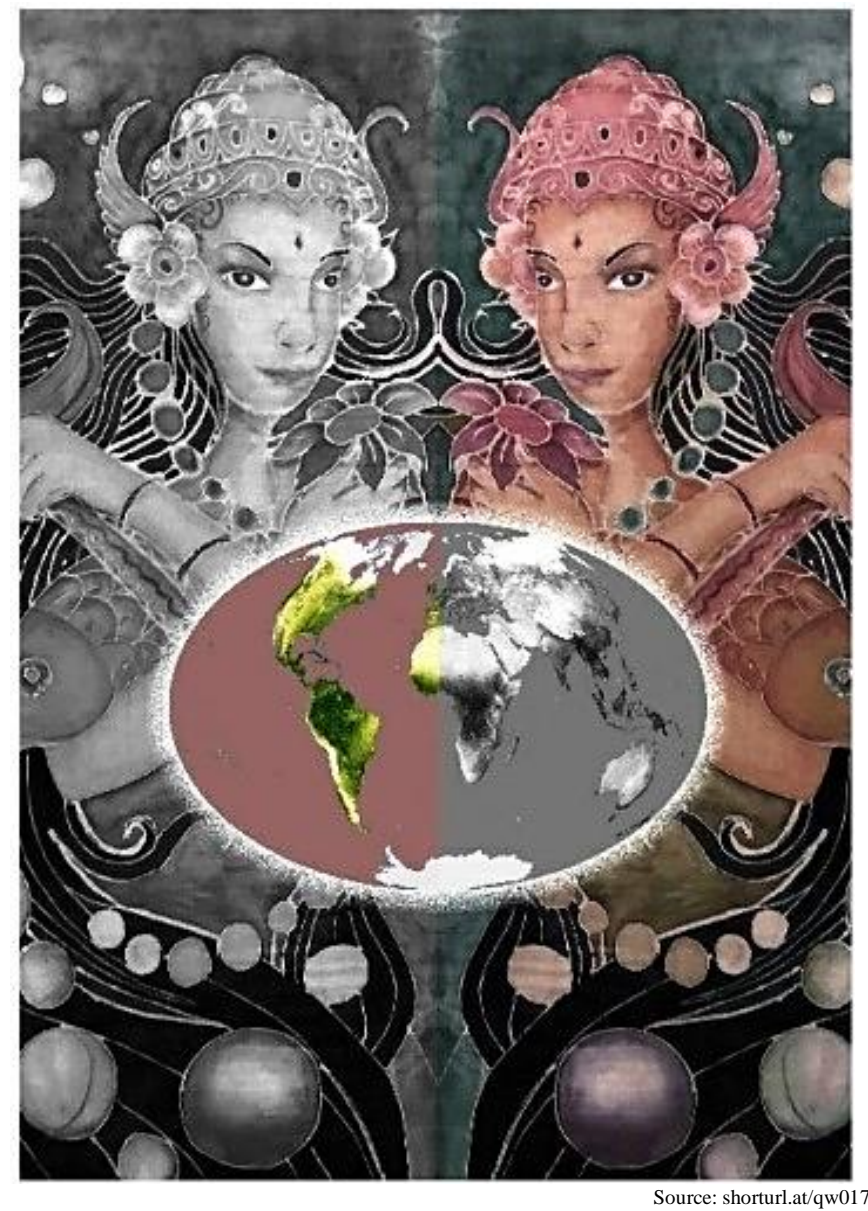

Fig. 5. Nyai Roro Kidul.

The visualization of this work (figure 5) was inspired by the batik cloth telling the story of Nyai Roro Kidul [20]. The artist processed it into a pandemic theme made with digital art. The artwork:

Nyai Roro Kidul Watch Us features a picture of 2 princesses. They are like an identical twin. But what distinguishes each other, is in the color. The one on the left in black and white, while the other on the right is pink, both in the clothes, the flower that is worn on the head and held in the hand, and the keris in the hand. The use of this color is different from the green color that is often used by Nyai Roro Kidul. The pink color gives this piece a feminine character. 
Nyai Roro Kidul a legend from Java known to be the ruler of land and ocean always appear is long hair against the background of the sea or big waves. She look after the mother nature. In addition, in this work the hair is depicted hanging down, but the top is covered by a crown, so that the hair is not visible. Unlike the previous version of Nyai Roro Kidul which did not use a topped crown

The two princesses in this work are joined by an ellipse with a white outline containing a map of the world. This map is divided into 2 sides, namely the left side which is pink and the right side which is black and white. The opposite of the background color.

The five artists whose works were discussed as samples in this study, ultimately have a place and way to channel their expression and creativity by communicating through online media, both individually and collaboratively. The visualized work departs from the traditions that come from his country. Local wealth is presented to the international community, full of messages about how dangerous Covid-19 is to hit the world.

\section{CONCLUSION}

Artist's cultural background play a great deal of contributing in creative ideas, long gone memories comes back and give a chance for someone to develop and put into their new perception. The emerging of childhood memories bring back the sensational emotion that stimulate ideas. Illustrative works are inspired by traditional elements, represent messages conveyed by artists, have a unique aesthetic appearance, seen from objects, visual elements, idioms, pay attention to the communicative aspects, and the creator's unique aspirations. each so that the appreciator can identify where the artist came from. The illustrative genre artwork at the 1st International Virtual Digital Art Exhibition, 'ASEDAS 2020: with the theme "Solidarity Against Covid-19", shows that artists, art educators, and academics in the arts are able to carry out creative activities within all boundaries. Even though they live in quarantine, they can convey things that have philosophical values of togetherness, solidarity and spirituality which emphasizes that there is no reason not to be creative, because art has the capability to build human civilization. In time, history will record its inspirations and traces that will show human life during the Corona 19 Virus pandemic that is currently sweeping the world.

\section{ACKNOWLEDGMENT}

The authors thank the Ministry of Research, Technology and Higher Education of the Republic of Indonesia for funding this research through the excellent applied research of higher education scheme 2020 and Universitas Kristen Maranatha for providing the facilities to realize this research.

\section{REFERENCES}

[1] Kartiwa, "Prodi Seni Rupa Murni-Maranatha Gelar Pameran Virtua untuk Donasi Kepedulian Penanggulangan wabah Covid-19 'I care therefore I exist," 2020. [Online]. Retrieved from: https://jabarbicara.com/prodi-seni-rupa-murni-maranatha-gelarpameran-virtual-untuk-donasi-kepedulian-penanggulangan-wabahcovid-19-i-care-therefore-i-exist/.

[2] A. Purwanti, Barometro: Gigih Menabung di Masa Pandemi. Jakarta: Kompas, p. 4, 2020.

[3] N. Ibrahin, A. Riana, D.B. Radius and Tunggal, Lelang Seni Rupa: Menolak Mati Meski Pandemi. Jakarta: Kompas, p. 1, 2020.

[4] S. Dhawan, "Online Learning: A Panacea in the Time of COVID-19 Crisis,” J. Educ. Technol. Syst., vol. 49, no. 1, pp. 5-22, 2020.

[5] P. Kabanda, "Work as Art: Links Between Creative Work and Human Development," 2016. [Online]. Retrieved from: http://hdr.undp.org/sites/default/files/kabanda_hdr_2015_final.pdf.

[6] J.W. Creswell, Penelitian Kualitatif dan Desain Riset. Yogyakarta: Pustaka Pelajar, 2014

[7] Tribun, "ASEAN Digital Art Society Menyelenggarakan Pameran Virtual Bersama 34 Negara "Fight Covid-19"," 2020. [Online]. Retrieved from: https://jabar.tribunnews.com/2020/06/06/asean-digitalart-society-menyelenggarakan-pameran-virtual-bersama-34-negarafight-covid-19 (accessed Sep. 20, 2020).

[8] M. Oppezzo and D.L. Schwartz, "Give your ideas some legs: The positive effect of walking on creative thinking," J. Exp. Psychol. Learn. Mem. Cogn., vol. 40, no. 4, pp. 1142-1152, 2014.

[9] A.B. Dwijonarko, "Seni Kriya Miniatur Kendaraan Tradisional UD. Permadi Desa Pohlandak Rembang Kajian Proses Pembuatan dan Bentuk Estetis," Eduarts : Journal of Arts Education, vol. 2, no. 1, pp. 1 8, 2013.

[10] D. Mustajab, A. Bauw, A. Rasyid, A. Irawan, M. A. Akbar, and M. A Hamid, "Working From Home Phenomenon As an Effort to Prevent COVID-19 Attacks and Its Impacts on Work Productivity," TIJAB (The Int. J. Appl. Business), vol. 4, no. 1, p. 13, 2020

[11] S. Kim, "Virtual exhibitions and communication factors," Museum Manag. Curatorsh., vol. 33, no. 3.

[12] Asedas, "Roro Jonggrang Vs Covid 19," 2020. [Online]. Retrieved from: shorturl.at/mBS38 (accessed Sep. 25, 2020)

[13] L.K. Manun, "Perancangan Batik Dengan Sumber Inspirasi Cerita Rakyat Dan Flora Fauna Indonesia,” J. Kriya-Ornamen, vol. 15, no. 02 , pp. 109-117, 2018.

[14] S. Endraswara, Folklor nusantara: hakikat, bentuk dan fungsi. Yogyakarta: Ombak, 2013.

[15] W. Ross, "Rara Jonggrang," in Cerita Rakyat 34 Propinsi, 1st ed. Jakarta: Sarang Baca, 2019, pp. 134-136.

[16] A. Pandanwangi and Nuning Damayanti, "Visualisasi Perempuan pada Lukisan Tradisional Tionghoa," Panggung, vol. 27, no. 2, pp. 117-129, 2017

[17] Asedas, "Survive and Recover from Covid 19," 2020. [Online] Retrieved from: shorturl.at/eipvR (accessed Sep. 25, 2020)

[18] Asedas, "Eradicate Covid 19," 2020. [Online]. Retrieved from: shorturl.at/blpGX (accessed Sep. 25, 2020).

[19] Asedas, "Save Civilization," 2020. [Online]. Retrieved from: shorturl.at/asGY8 (accessed Sep. 25, 2020).

[20] Asedas, "Nyai Roro Kidul Watch Us," 2020. [Online]. Retrieved from: shorturl.at/qw017 (accessed Sep. 25, 2020). 